\title{
A STUdy TO ESTABLISH THE MOST PLAUSIBLE BACKGROUND TO THE Fourth Gospel (JoHN)
}

\begin{abstract}
Authors:
Vhumani Magezi

Peter Manzanga ${ }^{1}$
\end{abstract}

\begin{abstract}
Affiliations:
${ }^{1}$ School of Ecclesiastical Sciences, North-West

University, South Africa
\end{abstract}

\section{Correspondence to: \\ Vhumani Magezi}

email:

vhumani@hotmail.com

\section{Postal address:}

George Whitefield

College, 64 Beach Road,

Muizenberg 7945,

South Africa

\section{Keywords:}

John's background; Fourth

Gospel background; Old

Testament background

to John; debate John's

Gospel; gospel of John

\section{Dates:}

Received: 16 Nov. 2009

Accepted: 09 Oct. 2010

Published: 29 Nov. 2010

How to cite this article:

Magezi, V. \& Manzanga,

P., 2010, 'A study to

establish the most

plausible background to

the Fourth Gospel (John)',

HTS Teologiese Studies/

Theological Studies 66(1),

Art. \#769, 7 pages. DOI:

10.4102/hts.v66i1.769

This article is available

at:

http://www.hts.org.za

(C) 2010. The Authors. Licensee: OpenJournals Publishing. This work is licensed under the Creative Commons

Attribution License.

\section{ABSTRACT}

The quest to establish a conceptual background of the fourth gospel has led to converging and diverging opinions. This study reviewed and compared literature on the fourth gospel to establish its most plausible background. In doing so, attention was given to the development of the debate on the religious backgrounds that possibly influenced the author in order to discover some fresh connections between the gospel and these suggested backgrounds. Reference is made to primary material such as the Dead Sea Scrolls, first century Palestinian Judaism, Josephus and Philo of Alexandria. The following proposed backgrounds were reviewed: Hellenistic Judaism, Philo of Alexandria, Gnosticism, Hermetic Literature, Mandaism, the Old Testament, Rabbinic Judaism, the Dead Sea Scrolls and the Samaritan background.

\section{INTRODUCTION}

Biblical studies that ignore the conceptual background of the author do not seem to do justice to the meaning of the text. This is also the case with the fourth gospel. To understand its message, a study of the background that impacted the author's thinking is important for a meaningful exegesis. In the past years, the quest for the conceptual background of the fourth gospel has led to converging and diverging opinions ${ }^{1}$. The question can be posed whether the suggested backgrounds are important to the reader in order to understand and interpret the fourth gospel. Should we find the relevant religious background, could it help us understand and interpret the fourth gospel more insightfully? In view of these questions, it is important to review the backgrounds that seem critical in providing insight to the understanding of the fourth gospel. In doing so, we will seek to understand the state of current scholarship in this regard. Gnosticism, Hellenistic thought and Palestinian Judaism will be our basis. However, these three main categories have their sub-categories, as shall be shown in this study.

\section{SUGGESTED BACKGROUNDS TO JOHN}

\section{Gnosticism}

The relation between the fourth gospel and Gnosticism has been debated for a long time and the debate is still far from settled (Murray 1987:lv). Bultmann (1971) was one of the scholars who posited that Gnosticism and John were closely related. Morris (1971:62) states that Bultmann 'is an outstanding example of a modern commentator who sees Gnosticism as the important part of the background to John'. Bultmann is the proponent of the idea that the Gnostic redeemer myth propels John's idea of Christ who came from God (Heaven) and returned to God. It is important to note that Bultmann based his view on Bousset and Reitzenstein (from the History of Religions School). Reitzenstein was convinced that he had

found an Iranian doctrine, that concerned the soul or the inner being as a divine being sent down from the world of light to the world of matter, from which it is once more released and summoned back.

(Munck 1962:227)

As a consequence, in the 1950s, the debate about the intellectual milieu of the fourth gospel was either a defense or refutation of Bultmann's (1971) 'controversial proposal that the gospel was written out of the context of an oriental Gnosticism' (Kysar 1975:103). A detailed study of Gnosticism reveals that it was composed of religious/philosophical systems. Dualism is at the core of this religion. Thus, matter is considered evil and special 'knowledge' is only possible to people through a special kind of revelation from the 'Redeemer'. Only the minority who gained such revelation (knowledge) were eligible for salvation. The 'Redeemer' of Gnosticism was sent from heaven in a disguised manner so that the hostile powers of the world would not identify him. God is viewed as holy and had no dealings with the material world.

Central to the fourth gospel is the fact that Christ gives salvation to people. However, questions can be formulated as to whether the mission of the Redeemer in Gnosticism and that of Christ the same or whether Christ, as our Redeemer, considers anything material to be evil. In the fourth gospel the author uses words like 'You are from below, I am from above' (Jn 3:19-20, 3:31, 6:38, 8:23, 15:19)2. Bultmann's followers asserted that this dualism is believed to be assimilated in the fourth gospel from Gnosticism. The coming down of Christ to reveal truth and his returning to heaven (Jn 3:13, 12:31-32) is considered to have a Gnostic background. Because of this, the proponents of Gnosticism consider Christ as the Logos-Redeemer.

1.C.H. Dodd listed the following areas that he thought could be useful for the interpretation of the fourth gospel: early Christianity, Hermetic Literature, Hellenistic Judaism: Philo of Alexandria, Rabbinic Judaism, Gnosticism and Mandaism. C.K. Barrett acknowledges Hellenistic Judaism with more emphasis on apocalyptic literature and Rabbinic Judaism. Still, Kilpatrick believes that the conceptual background to the fourth go fourth gospel.

2.Jesus also came down from heaven as the living bread $(6: 33,41,50,51,58)$ and later ascended to heaven $(6: 62)$ 
The author of the fourth gospel employs dualistic terms in his writing. These were possibly prevalent in his community. However, although he uses terms that in Gnosticism are used in a dualistic sense, this is not an assimilation of Gnosticism in the fourth gospel. Secondly, in his writing he reacts strongly against Gnosticism. For example, Gnosticism believed in a 'Redeemer myth' that could not mingle with the earth and humanity and that salvation is through knowledge. In contrast John talks about God (Jesus) who became flesh ${ }^{3}$ (Jn 1:14 cf. Ex 40:34) on earth and in the midst of mankind for the sole purpose of revealing the Father, so that man can be saved. Consequently, salvation according to John does not come by 'enlightenment'; instead, faith in Jesus is the pre-requisite for salvation. This marks a difference between the 'Redeemer myth' and the redeemer that John talks about.

Other Johannine scholars have thrown doubt on Gnosticism as the conceptual background of the author of the fourth gospel The first objection to this background is uncertainty as to the very existence of the 'Redeemer myth'. According to Morris (1971),

the existence of this Redeemer myth in any pre-Christian form is far from having been proved. So, for all its popularity in some circles this idea must be discarded. The Gnosticism we know is definitely second century.

(Morris 1971:63)

Van der Watt (2007:137) has a problem with the dating ${ }^{4}$ of the Gnostic writings. At the same time, many scholars are of the view that the ideas that led to the manifestation of an early recognisable Gnosticism were evident when John wrote the fourth gospel. But this does not mean that the author of the fourth gospel had Gnosticism as his conceptual background. Munck (1962:227-228) argues that Bultmann is wrong in proposing that the fourth gospel can be understood in light of the redeemer myth

Secondly, he notes that Bultmann (1971) never attempted to have a deeper analysis of the material he cites. He fails to

distinguish between probable dependence, the use of the same terminus technicus in the same sense, and in quite another sense, and the use of the same imagery in the same sense and quite in another and therefore probably entirely irrelevant sense.

(Bultmann 1971:227-228)

Munck's criticism appears to be opposing Gnosticism as the intellectual milieu of the fourth gospel's author.

Kysar (1975:103), like Morris, is of the opinion that Gnosticism belongs to the 2nd century. He goes on to say that it is not possible to prove that Gnosticism had influence on the formation of Johannine Christianity. Unlike Gnosticism, the fourth gospe teaches that the Son of Man took the human form (Jn 1:14). He later died and rose from the dead. Also, the fourth gospel teaches that mankind is saved from the bondage of sin through faith in the Son of Man. Salvation does not come through knowledge. Neil (1964) comments,

the fourth gospel knows nothing of an eternal, self-existent world of darkness, separate from the world of light... The Gnostic myth does not give us the clue that we need to the interpretation of the fourth gospel.

(Neil 1964:310)

We can look for it somewhere else.

In the light of this, it would be implausible to treat Gnosticism as the intellectual milieu of the fourth gospel's author. Gnosticism

3.In the Old Testament God's presence was found in the tabernacle, so Jesus fulfills the Old Testament in that he dwelt amongst people (6:35; 8:12; 10:7 cf. v.9; 10:11, 14: $11: 25 ; 14: 6 ; 15: 1$.

4.Van der Watt writes, 'A major problem in the debate is that the first available Gnostic documents only date from the second century CE. From a literary point of view, it is roce hat actully pre-date them. It should rather be the other way round, and many accept that Christianity influenced the emergence of Gnosticism, rather than the other way round'. actually undermines the life, death and resurrection of Jesus. Not only this, its view of man's relationship to God denies the importance of the person and work of Christ (Drane 1996:416) What Gnosticism teaches is not compatible with what the fourth gospel teaches. This leads us to study other backgrounds that some of the Johannine scholars have proposed.

\section{Hellenistic thought}

Firstly it has been proposed that John was probably dependent on Philo the Alexandrian Jew. Philo was a contemporary of Jesus. In his writings, Philo attempted to demonstrate how a Jew could comprehend his faith in the face of Hellenistic culture. Philo aimed at combining Judaism and Greek thought (Brown 1966:lvii). His treatment of the Old Testament was very similar to the way the Greek teachers treated Homer who allegorised their scriptures (Murray 1987:liv). It is also important to note that during Philo's time, 'rational thought had compromised with mysticism; eclecticism, both in philosophy and religion was the order of the day' (Barrett 1956:28). Thus, philosophy influenced the way Philo understood and expounded the Scriptures to convince the Gentiles (Greeks) that surrounded him; he allegorised the Old Testament. Is this approach reflected anywhere in the fourth gospel? Was the author of the fourth gospel dependent on Philo for his thinking? There are scholars who subscribe to the notion that John was dependent on Philo. For instance, Dodd (1963:33) unequivocally says, 'Rabbinic Judaism, Philo and the Hermetica remain our most direct sources for the background of thought'.

He also mentions that the Johannine Logos was identical with Philo's Logos. In other words, Dodd sees a direct borrowing of John from Philo. The Logos idea in the prologue has been used as the principal argument for Philo's impact on the author of the fourth gospel. Brown (1996), puts it best by saying that

Argyle attempts to show a wider dependence of John upon Philo because some of the biblical imagery used by John (Jacob's ladder, the brazen serpent, and the vision of Abraham) is used by Philo, precisely in connection with the doctrine of the Logos.

(Brown 1966:lviii)

John also uses the preceding images in his gospel, but he has moved beyond how Philo understands and interprets them Apart from the Logos, the use of symbolism seems to reinforce an affinity between John and Philo. To pick up on Dodd again he alludes to the symbolism of light, which he says is seen in both Philo and John. According to Philo, light is seen as a symbol of Deity in relation to man and the world. He uses light in many connections in his writings (according to Dodd). It seems appropriate to mention that John does not use light in different connections like Philo. Instead, in the fourth gospel Christ is the light of the world (Jn 8:12) and he is the only true light of men. 'Life' is another concept that has caused scholars to assert John's dependence on Philo. John speaks of the living water in 4:10, 14; 7:37-38. Similarly, Philo also refers to this (in De Fuga 199 and Leg 1:303). In Philo's case, the water is sometimes virtue, wisdom, but above all life itself (De Fuga 197-8) (Dodd 1963:56). The fourth gospel always connects life with Christ. To deny Christ is to be without life and to accept him is to have life. Murray (1987) says that

the declaration of John 1:14 and the function of the prologue to the Gospel as introducing the revelation and redemption of the Logos within the concrete situations of a local history were beyond Philo's horizons.

(Murray 1987:liv)

Further, Wilson (1953-1954:47-49) observes that both Philo and John use the Old Testament and the Wisdom Literature of the Old Testament. They (John and Philo) seem to run parallel, but their methodological procedures are dissimilar. The philosophical expressions, which are so colourful in Philo, do not exist in the fourth gospel. The allegories that Philo employs in his writings seem to have no parallels with the text of the fourth gospel. 
John (1:1-18) and Philo both speak of the Logos as clearly demonstrated in the prologue. The Logos is regarded by both as the mediator between God and man. It is also true that both demonstrate an Old Testament understanding as their background. We can say by using the word 'Logos' John is demonstrating an understanding that surrounded him, but he adapts the use of Logos ultimately to his own end. The Logos according to John becomes flesh, something that we do not learn about in Philo. Also, Philo takes a philosophical perspective in his understanding of the Logos. This is not found in the fourth gospel. Thus, John is not dependent on Philo even if he employs terms and biblical imagery parallel with Philo. The truth is that they shared a common background but the 'methodological procedure' was completely different (Brown 1966:lviii). This actually leads us to consider another background that could have influenced the thinking of the author of the fourth gospel.

Secondly, this leads us to the study of Hermetic Literature and John. Questions on whether the background of the fourth gospel was Greek or Jewish have been posed. Some have boldly claimed that the thinking that lies behind the author of the fourth gospel resembles the Greek Hermetic Literature. These were mystical writings purporting to give knowledge of God, produced in Egypt between A.D. 100 and 200 (Hunter 1985:9). The Hermetic Literature is found under the name of Hermes Trismegistus in antiquity. The man Hermes was regarded as very wise in Egypt; such that he was deified after his death as the god Thoth (Dodd 1963:11); this body of writing projects a fusion of Platonic and Stoic teaching. Painter (1991:53) says that Dodd uses the Hermetic writings to 'illustrate how John would have been read and understood by educated pagans'. The Hermetic Literature portrays some elements of semi-pantheism and Gnosticism. The Gnostic element is detected in the notion that salvation comes through revealed knowledge. This thinking is modeled by the Gnostics after John 17:3. Thus, by acquiring knowledge about God one becomes a perfect man according to Hermetism. Some parallels between the Hermetica and the fourth gospel have been established. The most prominent scholars who drew such parallels were C.H. Dodd and Braun. These two authors draw parallels that are almost similar but they judge them differently (Schnackenburg 1968:136). Dodd relies on the Hermetica for the interpretation and understanding of the fourth gospel. He acknowledges that there is no substantial borrowing between the Hermetic Literature and John. But he still thinks the Hermetic Literature forms the conceptual background of the fourth gospel as cited earlier (Dodd 1966:133). Other scholars do not subscribe to this view. In his article, Kilpatrick has expressed a great discontentment with the view posited by Dodd on the Hermetic Literature and John. Brown (1966) quotes him as follows:

Kilpatrick has stressed that the similarities between the two literatures should not be overemphasized. Some of the theological terms that are the most important in the Hermetica are totally absent from John, for example, 'gnosis', 'mysterion', 'athanasia' ('immortality'), 'demiourgos' ('demiurge').

(Brown 1966:lix)

John is considered closer to the Greek Old Testament (LXX) than the Hermetica. This lessens the likelihood of the Hermetica having influenced the author of the fourth gospel.

Neill (1964:324) disagrees with the notion that the Hermetic Literature had an influence on the fourth gospel. Brown and Morris comport with Kilpatrick (1957) who says,

we can discard the Hermetica with the Mandaean texts and other evidences of Gnosticism. They constitute no significant part of the background of the Gospel; they do not provide the key to its interpretation.

(Kilpatrick 1957:43)

Kilpatrick seems to find convincing background in the Greek Old Testament rather than other backgrounds. After all, Hermetic literature is believed to be 2nd and 3rd century by a number of scholars. Therefore, John cannot derive his thinking from the Hermetic literature (Williams 2002:2).
Thirdly, this leads us to the study of Mandaism and John. Another intellectual milieu that has been proposed is the influence of Mandaism on the fourth gospel. The Mandaean relationship to the fourth gospel has resulted in divergent views in scholarship. The debate is mainly inclined to finding parallels between the fourth gospel and Mandaism; currently, 'the attempt to derive the fourth gospel from Mandaean sources is already a curiosity of scholarship' (Morris 1987:lviii). The history and traditions of the Mandaeans cannot be accounted for with ultimate precision. Dodd (1963:115-130) furnishes us with a summary of the Mandaeans. Although he tries to give us a description of the Mandaeans he acknowledges that for, 'any history of the Mandaeans and their beliefs before 700 A.D we are dependent solely on inference and speculation' (Dodd 1963:115). Thus, their history cannot be narrated with precise accuracy.

However, this does not mean to say that some things cannot be known about the Mandaeans. There is a theory that the Mandaeans were a baptising sect in the Jordan Valley in the 1st century. Through the passage of time, their traditions became more established after a migration to Mesopotamia. According to Yamauchi they were non-Jewish, not properly acquainted with the Old Testament, spoke Aramaic and lacked a firsthand understanding of Christ and Christianity (Murray 1987:lviii). Their full-fledged theology reveals 'a highly syncretistic mixture of Jewish law, Gnostic myth, and Syrian Christianity' (Brown 1966:liv-lv). Dodd (1963:115-116) asserts that the Mandaean writings are composed of miscellaneous theology, myth, fairy tale, ethical instruction, ritual ordinances and dubious history. There is a lack of unity or consistency in their teaching. It is also not purely monotheistic or dualistic.

Explicit in the Mandaean teachings are the concepts of life and light, truth and lie, which are also found in the fourth gospel (Jn $1: 4-5,8-9,17 ; 3: 19-21 ; 8: 12 ; 11: 25 ; 14: 6 ; 15: 1)$. Brown (1966) also picks up on Bultmann by saying that

he supposes that the Mandaean thought represents a later derivative of the very type of Gnosticism that he postulates in the New Testament era among the disciples of John the Baptist and which served as a background for John. Hence he cites parallel symbols, thought patterns, and phrases in John and the Mandaean writings, and he looks on them as echoes of pre-Christian Gnosticism.

(Brown 1966:lv)

Bultmann and Baur maintained that Mandaism was the background which impacted the author of the fourth gospel. The opposing terms, light and darkness, life and death, have great prominence in the Mandaean literature. Entrance into the 'Kingdom' of life and light had a mythological understanding. This kind of understanding and teaching seems foreign and non-existent in the fourth gospel. Brown (1966:lv) suggests that the oldest forms of Mandaean theology available to us are late in the Christian era. Hence, there is no possibility of saying that John was influenced by this thought. He further hints that there is no Mandaean work that resembles John. He goes on to oppose Bultmann who cites parallel symbols, thought patterns and phrases in John and Mandaean writings and looks at them as pre-Christian Gnosticism. Sandmell cautions against such 'parallelomania' which seems not to help much (Carson 1991:59).

Mandaism seems to be a confused religion of myth, fairy tale, ethics, theology and dubious history (Williams 2002:2). It also leans heavily on Gnostic thinking in a number of ways which is a very late body of literature. We can therefore say there is a strong possibility that the Mandaean literature borrowed from the fourth gospel because of its lateness. This automatically dispels Mandaism as the conceptual background of the fourth gospel.

\section{The Old Testament quotations and allusions in the Fourth Gospel}

There are direct quotations and allusions to the Old Testament in the fourth gospel. Scholars say that the fourth gospel contains 
fewer Old Testament quotations than the synoptic gospels. Based on this idea some scholars have concluded that John did not know the Old Testament very well.

Some of the allusions that John makes are not very explicit, but their reality and origin cannot be doubted. For example, upon reading John 1:1-4 one is prompted to think of Genesis 1:1-5, but John does not furnish the reader with this background. Also, there are references made to Abraham (Jn 8:31-41), to Isaac (Jn 3:16 cf. Gn 22) and to Jacob (Jacob's ladder) (Jn 4:5f). All these examples demonstrate that the author is thinking of the Old Testament (Brown 1966:lx). The story of Moses and the Exodus receives noticeable allusion in the fourth gospel. This has led some scholars to suggest that the crafting of the fourth gospel resembles the Exodus. Smith (1962:329-342) in his article sees a close connection between Jesus' signs with the plagues that fell on Egypt. But some of the connections that Smith makes appear to be strained and artificial. Without following his pattern of analysis, we can still come up with clear references in John that show a similarity with Moses and the Exodus. For instance, John 1:17 makes reference to Moses in comparison with Jesus. The events of the Exodus are also clear in the fourth gospel: the giving of the manna (6:31ff); the water from the rock (7:38); the bronze snake (3:14); and the tabernacle (1:14) (Brown 1966:1x). John 19:36 makes an explicit remembrance of the Paschal lamb. Its bones were not supposed to be broken by the children of Israel according to Exodus 12:10, 46 and Numbers 9:12. The author of the fourth gospel is concerned to show that Jesus is the fulfillment of the Paschal lamb that was anticipated in the Old Testament by Israel. One can trace these events back to the Old Testament and link them to Moses and the Exodus without struggle. Also, the Old Testament quotations and allusions that John makes reveal that Jesus is greater than Moses and the Exodus experiences. Murray posits the idea that the theme of redemption is referred to in John 1:14. Murray (1987) seems to make a valid point by saying that,

the language used of the incarnation of the Logos is reminiscent of the dwelling of the Shekinah among the people of God in the wilderness and in John 1:17 (the law came through Moses, grace and truth through Jesus Christ).

(Murray 1987:lix)

The Shekinah that dwelt amongst the children of Israel finds its fulfillment in the person of Jesus who lived and continues to live amongst his people according to John.

Furthermore, the lifting up of the Son of Man (Ex 3:14) recalls the Exodus experience of the lifting up of the brazen serpent in the wilderness. The lifting up of Jesus on the cross brings eternal life and ultimate healing which the brazen serpent could not do. Also, the discourse on the bread of life recalls the manna given to Israel during her wilderness experience and that manna was pointing to the true Manna (Jesus Christ) (Jn 6:33). Jesus fulfills the main feasts of Israel that feature in the fourth gospel which: are the Passover (ch. 6), the Feast of Tabernacles (ch. 7) and the Feast of Dedication (ch. 10). It is at the Feast of Tabernacles where Jesus said, 'I am the light of the world' (Jn 8:12). Kysar (1975) observes that

the evangelist's traditions indicate that his community was acquainted with and drew upon a general stock of Old Testament knowledge common to Jewish and Christian instruction. More specifically, he was probably related to a community deeply immersed in the Wisdom tradition whose language and conceptuality is coined from the Old Testament $t^{5}$.

(Kysar 1975:106)

Finally, it should be noted that opinions differ on how John understood the Old Testament. But the common understanding amongst scholars is that the author's community was immersed

5.John's thought was couched in the Old Testament as could be seen in the following references (not exhaustive but illustrate the point): John 1:23 cf. Isaiah 40:3; John 3:14 of: Number 21:9; Jo $0: 31$ of. Exodus 16:4 and Psalm 78:23f; J0: 7:42 of. Micah 5:21; John 8:17 cf. Numbers 35:30; John 12:14-16 cf. Zechariah 9:9; John 13: 18 cf. Psalm 41:9; John 19:36 cf. Exodus 12:46 and Numbers 19:12. in the Old Testament. It seems that, whether John had a high or a low knowledge of the Old Testament, he seems to be very faithful in propagating the knowledge found in his tradition. He appears to be someone who has absorbed the Old Testament and pondered it deeply. Barrett (1956) says that

the Old Testament, therefore, was so well known and understood that John could use it not piecemeal but as a whole, may be taken as an essential element in the background of the gospel.

(Barrett 1956:25)

Schnackenburg (1968:124) also concedes that 'this gospel would be unthinkable without the Old Testament basis which supports it'. Thus, the Old Testament is an essential part of the conceptual background of the fourth gospel.

\section{Palestinian Judaism and John}

The echoes of rabbinic theology in the fourth gospel prompted the search for the relations between the two. In his recent work Johnson (2006:84) writes that 'one cannot doubt that the Jewish understanding of the background of the Gospel of John has become the predominant paradigm'. Some major sources of rabbinic theology are namely: the Mishnah, the Palestinian and Babylonian Talmuds, the Midrashim and the Targums (Gordon 1988:55). Dating of the rabbinic documents cannot be done with accuracy. They were written quite late, that is, after the fourth gospel. However, they contain some 'very early material going back to the time of Jesus and even before' (Brown 1966:lxi). John's familiarity with rabbinic thinking can be gleaned without much difficulty from the Old Testament passages that he cites. Barrett (1956:27) confirms that Rabbinic Judaism is the heir of Old Testament religion. Whilst Barrett is correct in what he says it is also well to be clear that Rabbinic Judaism is not an exact propagation of the Old Testament. The Rabbinic Literature covers a number of issues that seem to be foreign to the Old Testament. For instance, it deals with human activity and thought, criminal, civil and religious law. It also contains history that is mixed with folk tales, legends, liturgical details, biblical exegesis and some elements of mysticism are scattered in these writings. Some of the issues dealt with in this broad spectrum of theology are reflected in the fourth gospel.

For instance, in John 7:51, the protocol followed in bringing a criminal to justice is assumed. Nicodemus poses a question to the Jewish leaders. Their law could not condemn the accused without granting him the right to present his case before the judges. So before any condemnation was assumed, Jesus had the ultimate right to have a hearing before the judges. He was denied the right to do so in this incident. John is expressing the understanding of the rabbis as further confirmed in John 8:17. Jesus was accused of being his own witness. A fact could only be established if two witnesses testified the same thing against the accused. John reflects the rabbinic teaching and shows that Jesus did not breach the laws of the rabbis that were consistent with the Old Testament teaching. Also, the evangelist also projects knowledge of rabbinic interpretation of Scripture in (Jn 1:51). The verse recalls Genesis 28:12, where the angels ascended and descended on a ladder before Jacob's eyes. In the fourth gospel the angels ascend and descend on the Son of Man. In Midrash Rabbah lxix 3, a few rabbis read 'on him' (Jacob) instead of 'above it' as in Genesis 28:13. Some scholars say that the 'on him' is behind John's statement and this would mean that the Son of Man replaces Jacob (Brown 1966:90). Some scholars do not subscribe to this idea. But something that is clear in this is that the rabbis are dependent on the Old Testament for this story. In Midrash Rabbah lxviii:12 on Genesis 28:12, 'we find that Jacob's true appearance is in heaven while his body lies on earth, and the angels are traveling back and forth between them' (Brown 1966:90). Applying this to John 1:51, Murray (1987:lx) states, 'the Son of Man replaces Jacob and becomes the place of mediation to man of the revelation and redeeming powers of the kingdom of God'. Some scholars subscribe to this idea but they do so with some variations. Once more, the idea still finds its origins in 
Genesis 28:12-13. Also, the study of John 8:56, echoes Rabbinic exegesis which brings to mind Genesis 24:1 where Abraham 'went into the days of history and therefore saw in advance the day of the Messiah' (Barrett 1956:27)

The study of the law by the rabbis was considered to be life giving according to John 5:39. In the Mishnah, ${ }^{6}$ the studying of the Torah was something that a man needed to spend his time on. Aboth (1:5b) cautions that 'So long as a man talks too much with a woman he brings trouble on himself, wastes time better spent on studying the Torah, and ends up an heir of Gehenna'. In Proverbs 6:23 (cf. Ps 119:105) we learn that the commands of God are a lamp and those who learn from them have light. In the fourth gospel, the evangelist is clear in saying that the Scriptures (Torah) testify about Christ and they have their fulfillment in him. In other words, believing in the Scriptures without believing in the one they testify about could not save the rabbis (according to John). In terms of these sources Barrett (1956) notes that

No part of the Rabbinic literature was written down until a date later than the composition of John. Direct literary relationship is out of question, and some apparent parallels may be merely fortuitous. But when all such allowances have been made it remains very probable that John himself was familiar with the oral teaching which at a later date was crystallized in the Mishnah, the Talmud and the Midrashim.

(Barrett 1956:27-28)

Morris (1971:60) acknowledges that the teachings of the Rabbis cannot be over-looked in studying the fourth gospel. However, he notes that the readers needed to be on their guard for the rabbinic sources have a late date. We need not exaggerate the parallels we make. The nature of the relationship between John and these sources is that they are both aware of the Pharisaic Judaism of Jesus' time. Also, the rabbinic sources bear witness to the Old Testament and John shares the same background. Thus, the study of the Old Testament and Rabbinic Judaism can help us understand the fourth gospel better; to say that Rabbinic Judaism forms part of John's conceptual background is not far fetched.

This leads us to the study of the Qumran Revolution and John. Josephus mentions three Jewish philosophical schools in $\mathrm{War}^{7}$ (2:119-121) which include the Pharisees, the Sadducees and the Essenes. The description that Josephus gives about the Essenes has made them possible candidates for the writing of the Dead Sea Scrolls. In War (2:122) Josephus says that 'Those entering the sect transfer their property to the order'. This description is reflected in The Community Rule (1QS). A further description of this sect is found in War 1:11-12; 5:1-2 and In Ant 13:173. They are also known for their strict observance of Torah and taking solemn oaths of piety and obedience. According to War (2:137138), those who wish to join the Essenes sect were put on trial for one year; their rules, which were stricter than those of the Pharisees and Sadducees, are seen in War 2:147. Because of their differences with other Jewish religious philosophical groups they withdrew to the Judean desert under the leadership of the Teacher of Righteousness. They wanted to wait for the Messiah without any defilement (from the Romans and other Jews) and to prepare the way of the Lord (Is 40:3).

However, we are concerned with finding out if the Dead Sea Scrolls contributed anything to the conceptual background of the fourth evangelist. Hunter (1968) said of the Dead Sea Scrolls:

they give us a body of thought, which may provide an actual background for the fourth gospel, both in date and place (southern Palestine in the first century B.C/A.D) and in basic theological affinity.

(Hunter 1968:27)

6. These references are taken from The Mishnah: A New Translation (by Jacob Neusner 1988).

7.For convenience sake, I will be using 'War' instead of The Jewish War. And for The Antiquities of the Jews, I will be using 'Ant'.
Kümmel (1975:158) also asserts that 'John and Qumran presuppose a common background, but the thought world of Qumran cannot be the native soil of the Johannine thought forms'. Kümmel could be making a valid point by saying there is a 'common background' but the way John and the Qumran understand and develop their theology is different. For instance, the Qumran sect looked forward to the coming of the Messiah for their deliverance. But for John the Messiah has come and has brought redemption to his people.

Important for the comparison in terms of the fourth gospel is the Qumran attitude to the Temple and its priesthood (Murray 1987:lxi). They considered themselves as the actual temple of God and the absolute faithful priesthood. There is a repeated reference to this in The Community Rule and other documents. 1QS 8:58, 'At that time, the men of the community shall set apart a House of Holiness for the community of Israel, for those who walk in perfection'. The fact that they lived in holiness led them to consider themselves as the 'Temple of God'. The preceding reference could have some similarities with John 2:19-21. It is in verse 19 where Jesus says, 'Destroy this temple, and I will raise it again in three days'. His body is the temple according to John, but the meaning and the thought forms of John and Qumran are different.

The Qumranians spoke about the resurrection or rescue from death and entrance into life (see $1 \mathrm{QH} 3: 20)^{9}$. In the fourth gospel, the teaching on resurrection is directly linked with Jesus. He made an emphatic declaration that he is the resurrection and the life (Jn 11:25). They also believed in the remission of sins and becoming a new creation. There is also mention of the Holy Spirit who will be given to them in the last days. All this understanding is related to salvation (cf. 1QH 11:11-14; 16:8-12 and 1QS 11:2-9). But the salvation of the Qumran and that of the fourth gospel has a difference. Salvation at Qumran did not have its focus on the realized eschatology found in the fourth gospel (Murray 1987:lxiii). Nevertheless, their anticipation of eternal life after being resurrected from the dead has some relations with John. There is also mention of the Holy Spirit in John and the Qumran (1QS 11:510; $\left.1 \mathrm{QH} 14: 10^{11}\right)$. It is often considered that the Paraclete doctrine of John is rooted in the Qumran teaching (Murray 1987:lxiii). But Murray adds that the word 'rooted' seems not to be the right word to use here. Thus, a common milieu between John and the Qumran is possible.

This Qumran sect was more concerned with itself as the sons of light and was proud both in its present state and future victory. John is more concerned with what God is going to do in Christ. The coming of Christ for John revolutionises everything. It is no wonder he says that Jesus is also the Light (Jn 8:12) and the truth (Jn 14:6) and the Spirit of Truth will help those who believe in him to overcome evil. Another important fact is the brotherly love in John and the Qumran. In the Qumran literature, the sons of light are commanded to hate the sons of darkness in 1QS 1:10. Harsh curses were also pronounced on the sons of darkness (1QS 2:5-10). In John 13:34-35; 15:12 there is an emphasis on loving the brother in Christ and it is not the case with the Qumran. Thus, there is a difference between John and the Qumran.

However, both John and the Qumran demonstrate an understanding of the Old Testament. But this may not make all the parallels genuine and intimate. Morris (1969:328) cautions that the similarities existing between the Qumran and John 'should not be overlooked' and adds that the differences are

8.All the quotations on the Dead Sea Scrolls are taken from Geza Vermes The Dead Sea Scrolls in English, 1995 (except where indicated).

9.'I thank Thee, O Lord for Thou hast redeemed my soul from the Pit and from hell of Abaddon Thou raised me up to everlasting height.

$10 . ' \ldots$ with the everlasting host and with (Thy) spirits (of holiness), to be renewed together with all the living and to rejoice together with them that know.

11.'Thou hast shed Thy Holy Spirit (upon me) and thus drawn me near to understanding Thee. 
striking. Brown (1966) argues that

the parallels are not close enough to suggest a direct literary dependence of John upon the Qumran literature, but they do suggest Johannine familiarity with the type of thought and vocabulary exhibited in the scrolls.

(Brown 1966:lxiii)

The 'type of thought' is that of the Old Testament and first century Palestinian Judaism. Finally, both share a common background but they sometimes express it differently.

Finally, this leads us to study the Samaritan background to the fourth gospel. The Samaritan religious traditions have been assumed to have some affinities with the fourth gospel. John shows more interest in the Samaritans than the synoptic gospels. The reflection of Samaritan religious traditions in the fourth gospel has led scholarship towards a Samaritan Background. Bowman in his article (Samaritan Studies 1958) furnishes us with the five-point creed of the Samaritans. He says that they had a belief in God, in Moses, in the Scriptures, in Mount Gerizim and in the Day of Vengeance. Such were also the basic beliefs of the Jews with the exception of the belief in Mount Gerizim as the place where God is to be worshipped (Murray 1987:lxiii). The Samaritans believed that Mount Gerizim was the place where God had to be worshiped according to John 4:20. The Jews worshipped God in Jerusalem.

The Samaritans focused on Moses with great attention. He revealed God to them through the Torah. This resulted in them also identifying him with the word and the light (possibly just like John the Baptist as a witness concerning the Light). Similarly, the Jews also hold Moses in high regard because he received the Torah from God. A substantial amount of material has been written on the Samaritans ${ }^{12}$. It is true that John gives them greater attention than the synoptics as stated earlier (Jn 4) Possibly John would like to show them that their belief in Moses as the word, light, revealer, redeemer etc; finds its fulfillment in Jesus. Murray (1987:lxv) says that, a closer look at Johannine Christianity shows that it is not founded on Mosaic traditions. Instead, the Son of Man and Son of God concept appearances are crucial for the Christology of the fourth gospel. He also adds that we cannot assign the concepts of Logos, light, life, Saviour and Paraclete to Moses. In the same vein, Keener (2003) argues that

There is a further practical problem with appealing to a 'Samaritan background' for the fourth gospel: nearly all our sources for Samaritan theology are quite late-generally medieval. It is quite precarious to reconstruct Samaritan theology in the first century and use it as backdrop for Christian documents which long precede the extant Samaritan sources and could have influenced them. We cannot deny the possibility of some Samaritan Christian thought in the Johannine community or among those who influenced it. But we lack sufficient evidence to make it a context of the Gospel.

(Keener 2003:170)

Keener and Murray therefore agree that there is a possibility of Samaritan influence but they do not overemphasize the point This field is still open for further investigation. We cannot say with confidence that the Samaritan background is the milieu of John. One would need to come up with more convincing evidence of a Samaritan background for John.

\section{CONCLUSION}

This study has attempted to review the religious background that could have influenced John. Bultmann suggested that Gnosticism could be an important background to understand the

12.Bowman, J., 1958, 'Samaritan Studies', Bulletin of the John Rylands University library of Manchester 40, 298-327. Freed, E.D. 1970, 'Did John Write His Gospel Partly to win Samaritan Converts?', Novum Testamentum 12, 241-256. Buchanan, GW 1968, 'The Samaritan Origin of the Gospel of John', in J. Neusner (ed.), Religions in Antiquit, pp. 149-175, Brill, Leiden. Scobie, C.H.H. 19712-1973, Religions in Anliquity, pp. 149-175, Bril, Leiden. Scobie, C.H.H., 19712-1973, 'The Origins and Development of Samaritan Christianity', New Testament Studies $19,390-414$. fourth gospel. The dualistic terms and statements in Gnosticism and John have been the basis of this view. Gnosticism believes in a 'redeemer' that could not mingle with the material world and that salvation comes through knowledge. However, John talks about God who takes human form and mingles with humanity (1:14). Also, salvation does not come through knowledge but through faith in Jesus. John's frame of mind is antithetical to many of the ideas of later Gnosticism. Thus, to say that Gnosticism formed his milieu is tenuous.

Secondly, there are good points of contact between John and Philo (Jew of Alexandria), especially in the prologue (Jn 1:1-18). Both refer to the Logos as the mediator between man and God:

Even if John did take the idea from Philo, his conception of the Logos is radically transformed. Philo uses the plural 'logoi' on occasions. The Word becomes incarnate in Christ, an idea quite alien to Philo.

(Williams 2002:1)

Also, they are both indebted to the Old Testament for their background but how they use it is completely different. The philosophical and rationalistic approach in using the Old Testament of Philo is missing in John.

Thirdly, the Hermitic Literature and Mandaism are some of the proposed backgrounds of the fourth evangelist. The Hermitic Literature makes use of terms like 'light' and 'life' and many others similar to John. Because this body of literature is considered to be second and third century, John was not influenced by it in any way. On the other hand, Mandaism is a confusing mixture of myth, theology, ethics and dubious history; it is also considered to be very late. Thus, Mandaism borrowed from John, not John from Mandaism. The current scholarship says that the Old Testament, Rabbinic Judaism and the Dead Sea Scrolls are the most probable backgrounds against which the fourth gospel could be read and understood. Thus, the Old Testament and its development in first century Palestinian Judaism is the most plausible background against which to understand and interpret the fourth gospel.

\section{REFERENCES}

Barrett, C.K., 1955, Gospel According to John, SPCK, London.

Barrett, C.K., 1978, The Gospel According to St John: An Introduction with Commentary and Notes on the Greek Text, 2nd edn., SPCK, London.

Bruce, F.F. 1988, New Dictionary of Theology: Dead Sea Scrolls, ed. S.B. Ferguson \& D.F. Wright, Inter-Varsity Press, Routledge.

Brown, R.E., 1966, The Gospel According to John I-XII: The Anchor Bible, Geoffrey Chapman Publishers, London.

Bultmann, R., 1971, The Gospel of John: A Commentary, Westminster Press, Philadelphia.

Carson, D.A., 1991, The Gospel According to John, Eerdmans Publishing Company, Michigan.

Charlesworth, J.H., 1985, The Old Testament Pseudepigrapha: Volume 1E 2, Doubleday, New York.

Dodd, C.H., 1968, Interpretation of the Fourth Gospel, University Press, Cambridge.

Drane, J.W., 1996, New Bible Dictionary Third Edition: Gnosticism, ed. H.I. Marshall \& A.R. Millard, Inter-Varsity, Leicester.

Goldstein, J.A., 1983, The Anchor Bible: II Maccabees, Doubleday, New York.

Gordon, R.P., 1988, New Dictionary of Theology: Rabbinic Theology, ed. B.S. Ferguson \& D.F. Wright, Inter-Varsity Press, Leicester.

Hunter, A.M., 1965, The Gospel According to John, Cambridge University Press, London.

Hunter, A.M., 1968, According to John: A New look at the Fourth Gospel, SCM, London.

Johnson, B.D., 2006, 'Salvation Is from the Jews': Judaism in the Gospel of John: New Currents Through John A Global Perspective (Number 54), ed. F. Lozada Jr. \& T. Thatcher, Society of Biblical Literature, Nijmegen.

Keener, C.S., 2003, The Gospel of John: A Commentary Volume One $\mathcal{E}$ Two, Hendrickson Publishers, Peabody, MA. 
Kilpatrick, G.D., 1957, The Religious Background of the Fourth Gospel (in Studies in The Fourth Gospel, ed. F.L. Cross, SCM, London.

Kümmel, W.G., 1975, Introduction to the New Testament, SCM, London.

Kysar, R., 1975, The Fourth Evangelist and His Gospel: An examination of Contemporary scholarship, Augsburg Publishing House, Minneapolis, MN.

Kysar, R., 1986, Augsburg Commentary on the New Testament: John, Augsburg Publishing House, Minneapolis, MN.

Morris, L., 1969, Studies in the Fourth Gospel, The Paternoster Press, London.

Morris, L., 1971, The Gospel According to John, Eerdmans, Grand Rapids.

Munck, J., 1962, 'The New Testament and Gnosticism', in W. Klassen \& G.F. Snyder (eds.) Current Issues in New Testament Interpretation, n.p., SCM, London.

Neil, S., 1964, The Interpretation of the New Testament 1861-1961, Oxford University Press, New York.

Neusner, J., 1988, The Mishnah: A New Translation, Yale University Press, London.

Painter, J., 1991, The Quest for the Messiah: The History, Literature and Theology of Johannine Community, 2nd edn., Nashville, Abingdon.
Schnackenburg, R., 1968, The Gospel According to John: Volume 1, Burns and Oates, London.

Schnackenburg, R., 1979, The Gospel According to St John: Volume 2, Crossroad, New York.

Van der Watt, J., 2007, An Introduction to the Johannine Gospel and Letters, T \&T Clark, London.

Vermes, G., 1995, The Dead Sea Scrolls in English: Revised and Extended Fourth Edition, Penguin Books, New York.

Whiston, W., 1960, Josephus: Complete Works, Pickering and Inglis LTD, London.

Williams, B., 2002, New Testament: John's Gospel, Bible Institute of South Africa, Kalk Bay.

Wilson, R.Mcl., 1953, 'Philo and the Fourth Gospel', Expository Times 65(1953-1954), 47-49.

Wise, M., Abbegg, J.R. \& Cook, E., 1996, The Dead Sea Scrolls: A New Translation, Harper Collins Publishers, London.

Yonge, C.D., 1993, The Works of Philo: Complete and Unabridged, new updated version, Hendrickson Publishers, Peabody, MA. 